Original Article

\title{
Evaluation of Fig Jam By-Product as an Energy Source in Florida Red Tilapia, Oreochromis, Niloticus $x$ Oreochromis Mosambicus Diets
}

\author{
A. Y. El-Dakar ${ }^{1}$, A. I. Abd Elmonem² and S. M.M. Shalaby ${ }^{3}$ \\ ${ }^{1}$ Fish Resources and Aquaculture Department, Faculty of Environmental Agricultural Sciences, Suez Canal \\ University, El-Arish. Egypt. ${ }^{2}$ Animal and Fish Production Department, Faculty of Agriculture, Alexandria \\ University, El-Shatby Alex, Egypt. ${ }^{3}$ National Institute of Oceanography and Fisheries, Alexandria, Egypt.
}

\begin{abstract}
Search on new feedstuff as energy sources in fish diets to reduce feed cost is significant importance. Agro-industry by-products including fig jam by-products (FJB) promising to serve as unconventional energy sources. Full or partial replacement of the wheat bran component by FJB in the diets of Florida red tilapia, Oreochromis niloticus x Oreochromis mosambicus, fingerlings were examined. Five isonitrogenous and isocaloric diets were formulated to contain $0,5,10,15$ and 20\% FJB, which represented to $0,25,50,75$, and $100 \%$ replacement level of wheat bran, respectively. Ten fish $(2.13 \mathrm{~g} /$ fish) were randomly distributed into 10 experimental groups in duplicates and reared for eight weeks. Performance of fish fed diets containing 25 and 50\% replacement levels were not affected significantly $(\mathrm{P}>0.05)$ compared to the control diet. However, at higher levels of FJB (70 or $100 \%)$, the growth performance and feed conversion ratio $(\mathrm{FCR})$ were significantly lower $(\mathrm{P}<0.05)$ than the control group. Protein efficiency ratio (PER), productive protein value (PPV) and energy retention (ER) decreased at the higher replacement levels. Body composition was not affected using different replacement level of FJB. No significant differences $(\mathrm{P}>0.05)$ were observed in incidence cost and profit index among fish fed 25 and $50 \%$ FJB replaced wheat bran.
\end{abstract}

Key Words: Red tilapia, Fig jam by-product, Nonconventional, Feedstuff, Growth, Feed conversion

Received : 3 July 2007

Accepted : 20 December 2007

Correspondence:

Ashraf Y. El-Dakar

Fish Resources and Aquaculture Department, Faculty of Environmental Agricultural Sciences, Suez Canal University,

El-Arish. Egypt. Tel.: +202126129896, Fax: +0683320387

E-mail: a_eldakar@yahoo.com

Copyright : All rights reserved to Mediterranean Aquaculture and Environment Society (MAES) 


\section{Introduction}

Finding economical sources of fish ingredients and prices for used products have been raised. This problem is more serious in developing countries e.g. Egypt. Considerable emphasis has been focused on the use of conventional plant oil seed meals including soybean, groundnut, cotton seed and rapeseeds meals (Jackson, et al. 1982 and Robinson, et al. 1984). Recently, interest has been conducted on the evaluation and use of unconventional feedstuff such as aquatic marcophytes, agriculture by-products, single cell protein, peanut meal, algal powder, etc. (Munsiri and Lovel, 1993; Lim, 1997; Mukhopadhyay and Ray, 1999). In Egypt, a considerable attention has been paid to use nonconventional feedstuffs either as protein or energy sources to replace fishmeal and yellow corn which represent the largest part of commercial feeds (Shalaby, 1998; El-Dakar, 1999; Ghazalah, et al. 2002; Osman, et al. 2003 and Abdel-Hakim, et al. 2003). Many researchers used agro-industrial by-products as energy sources in fish diets e.g. tomato waste and pea waste (Masaoud, 1992), seaweeds, (Zaki, 1990), Egyptian mallow (Labib, 1990), leaves of some vegetables (Abdel Munaem, 1998 and El-Dakar, 1999). Substantial quantities of crop residuals and industrial by-products could be used in formulation fish diets. However, many of these unconventional feeds did not maximally utilized by fish producers due to inadequacy evaluation of their nutritive value and/or their inadequacy benefits. Belal and Al-Jasser (1997) fed tilapia $O$. niloticus various levels of date waste $(15,30$ and 45\%) as replacement for starch. They found that weight gain, FCR, and PER improved with diet containing date waste as compared with starch diet.

Figjam by-product is one of these unconventional sources. Fig (Ficus carrica) belongs to genus Ficus and this genus belongs to family Moracease. It contains sugary and citric acid. It is well known in the Mediterranean countries where its genetic resources are still available in Syria, Lebanon and Arab Peninsula. The fruit usually is consumed fresh locally or in dried, canned and preserved form. Dried figs and those unfit for human consumption, can be used as animal fodder (http://www.hort.purdue.edu/newcrop/ proceedings 1996/V3-416.html\#Fig). Today, the fig is a moderately important world crop, with an estimated annual production of more than one million tons of fruit. Total production of fig in Egypt is 216.59 thousand tons (AOAD, 1998). Therefore, the present study aimed to evaluate of the nutritive value of this waste (FJB) and study the effects of its replacement with wheat bran on growth performance, feed conversion, nutrient utilization, body composition and cost-benefit analysis of red tilapia fingerlings.

\section{Materials and Methods}

This work was carried out at the Wet Fish Lab. Faculty of Agriculture, Alexandria University. Ten glass aquaria with dimensions of $70 \times 30 \times 40 \mathrm{~cm}$, total net volume $70-\mathrm{L}$, were used in this study. All aquaria were filled with dechlorinated tap water stored 24 hours before use. Florida red tilapia, $O$ niloticus $x O$ mosambicus, were obtained from the Maryot Fish Farming Co. Fish were transported in fiberglass tanks (300L). All fish were kept for one week to alleviate stresses and to be adapted to the new conditions. Ten fish with the initial weight $(2.13 \mathrm{~g} / \mathrm{fish})$ were randomly selected and allotted into the experimental aquaria. Fish were fed the control diet for two weeks, during this period healthy fish of the similar weight replaced dead ones.

Five diets were formulated to contain 0, 5, 10, 15 and $20 \%$ of FJP replaced wheat bran, corresponding to $0,25,50,75$ and $100 \%$ substitution level, respectively. Each diet was fed to randomly assigned duplicate aquaria. Ingredient composition of the diets is presented in (Table 1). Fishmeal was home made by collecting small fish and non-saled fish named locally "Wazafa", dried at $60^{\circ} \mathrm{C}$, ground and sieved prior to be kept at $-20^{\circ} \mathrm{C}$. The diets were prepared by mixing dry ingredients with water and were pelleted using a meat mincer with a 1-mm diameter. The pellets were air dried and 
Table 1. Ingredients composition of the experimental diets.

\begin{tabular}{|c|c|c|c|c|c|}
\hline \multirow[t]{2}{*}{ Ingredient } & \multicolumn{5}{|c|}{ Diets No. } \\
\hline & 1 & 2 & 3 & 4 & 5 \\
\hline Fish meal & 35 & 35 & 35 & 35 & 35 \\
\hline Soybean meal & 30 & 30 & 30 & 30 & 30 \\
\hline Wheat bran & 20 & 15 & 10 & 5 & 0 \\
\hline Corn starch & 8 & 8 & 8 & 8 & 8 \\
\hline Fig. jam by-product (FJB) & 0 & 5 & 10 & 15 & 20 \\
\hline Corn oil & 5 & 5 & 5 & 5 & 5 \\
\hline Vitamin mix. $^{1}$ & 0.875 & 0.875 & 0.875 & 0.875 & 0.875 \\
\hline Ascorbic acid & 0.125 & 0.125 & 0.125 & 0.125 & 0.125 \\
\hline Mineral mix. $^{2}$ & 1 & 1 & 1 & 1 & 1 \\
\hline Total & 100 & 100 & 100 & 100 & 100 \\
\hline \multicolumn{6}{|c|}{$\begin{array}{l}\text { 1. Vitamin mixture (g/100 g) was } 960000 \mathrm{IU}, 160000 \mathrm{IU}, 0.8 \mathrm{~g}, 80 \mathrm{mg}, 0.32 \mathrm{~g}, 0.12 \mathrm{~g}, 0.8 \mathrm{~g}, 0.8 \mathrm{mg} 1.6 \mathrm{~g}, 80 \mathrm{mg}, 4 \mathrm{mg}, 40 \\
\text { of vitamin A, D3, E, K, B1, B2, B6, Pantothenic acid, B12, Niacin, Folic acid Biotin, Choline chloride, respectively. }\end{array}$} \\
\hline \multicolumn{6}{|c|}{$\begin{array}{l}\text { 2. Mineral mixture }(\mathrm{g} \backslash 100 \mathrm{~g}) \text { was } 12.75,72.85,0.55,0.25,0.02,5,2.5,0.08,0.05,0.01 \text { and } 6 \mathrm{mg} \mathrm{of} \mathrm{MgSO}_{4} .7 \mathrm{H}_{2} \mathrm{O}, \mathrm{CaHPO}_{4} \text {. } \\
2 \mathrm{H}_{2} \mathrm{O}, \mathrm{ZnSO}_{4} \cdot 7 \mathrm{H}_{2} \mathrm{O}, \mathrm{MnSO}_{4} \cdot 4 \mathrm{H}_{2} \mathrm{O}, \mathrm{CaI}_{2} \cdot \mathrm{O}_{6} \cdot 6 \mathrm{H}_{2} \mathrm{O}, \mathrm{KCl}, \mathrm{FeSO}_{4} \cdot 7 \mathrm{H}_{2} \mathrm{O}, \mathrm{CuSO}_{4} \cdot 5 \mathrm{H}_{2} \mathrm{O}, \mathrm{CoSO}_{4} \cdot 7 \mathrm{H}_{2} \mathrm{O}, \mathrm{CrC}_{3} \cdot 6 \mathrm{H}_{2} \mathrm{O} \text { and NaCl} \text {, } \\
\text { respectively. }\end{array}$} \\
\hline
\end{tabular}

stored at $-20^{\circ} \mathrm{C}$. The pelleted feeds were slightly broken into particles during the first two weeks. Fish were fed 8,6 and $4 \%$ of the body weight daily for 1-2, 3-4 and 5-8 weeks, respectively. The feed amount was given three times a day (900, 1200 and 1500) in equal proportions. Feeding was performed for six consecutive days, for 56 days. Fish were weighed biweekly and feed amounts were adjusted to weight. Fish were reared in $28 \pm 2^{\circ} \mathrm{C}$ and $8.8 \pm 0.2$ for temperature and $\mathrm{pH}$, respectively. Third water volume was exchanged daily except the weighing day, about two thirds of water volume were changed.

Diets and fish samples were analyzed according to AOAC (1990) for dry matter, crude protein, ether extract, crude fiber, nitrogen free extract (NFE) and ash. The gross energy contents of the diets and fish samples were calculated using factors of $5.65,9.45$ and $4.2 \mathrm{kcal} / \mathrm{g}$ of protein, lipid and carbohydrate, respectively (NRC, 1993). Digestible energy content was calculated from standard physiological fuel values as 4 and $9 \mathrm{kcal} / \mathrm{g}$ of protein, carbohydrate and lipid, respectively (Garling and Wilson, 1976). To evaluate cost-benefit analysis of FJB inclusion in the diets of red tilapia fry, incidence cost (IC) and profit index (PI) were calculated according to New (1985). Analysis of variance (ANOVA) was carried out according to Snedecor and Cochran (1974) using a completely randomized design (CRD). Differences were subjected to Duncan's Multiple Range-Test (Duncan, 1955) at a significance level of 0.05 . Software of MSTAT-C was used to compute the statistical analysis.

\section{Results and Discussion}

Fig jam by-product contains a reasonable amount of $(60.69 \%)$ which indicated a potential value as a source of energy. However its high content of $(11.9 \%)$ is a factor limits its usage as a feed for fish. The gross energy content of such source could be considered as classic energy sources e.g. yellow corn which recorded 4200 $\mathrm{kcal} / \mathrm{kg}$ (Ghazalah, et al. 2002).

When FJB replaced wheat bran at 0,25 or $50 \%$ no significant differences $(\mathrm{P}>0.05)$ were observed among these replacement levels 
compared to the control regarding body weight, total gain and specific growth rate while the higher levels of substitution showed negative effects on performance of red tilapia. This may be attributed to the higher crude fiber content of FJB $(11.9 \%)$. These results are in agreement in literature (Hasanain, 1991; Masaoud, 1992; ElAiatt, 1999 and Ghazalah, et al. 2002). Similar trend showed inferior performance when red tilapia fed peas waste and tomato waste at 10 , 20 and 30\% (Masaoud, 1992) due to its higher crude fiber content. On the other hand, El-Aiatt (1999) found that the percentage of weight gain was affected by the replacement of wheat flour in diets by nonconventional carbohydrates sources were $62,38,24$ and $24 \%$ for olive waste, eggplant leaves, acacia leaves and pepper leaves, respectively. Weight gain, SGR, FCR and PER of $O$. niloticus were improved with diets containing 15,30 or $45 \%$ of date waste (Belal and Al-Jasser, 1997). El Baghdadi (1995) concluded that date stone meal could be used in laying quail diet up to $12 \%$ without detrimental effect on productive performance. This may be attributed to the presence of hormonal like compounds which acts as a growth promoter and results in an increase weight and growth performance of animals (Barreveld, 1993).

In the present study, when used containing FJB in tilapia feeds significant differences $(\mathrm{P}<0.05)$ in performance had been detected particularly at the higher replacement levels (75 and $100 \%$ ). However, at 25 and 50\% replacement level, the performance of fish was not affected significantly compared to the control diet (Table 2). In this concern, Hulan et al. (1982) concluded that potato waste as an energy source could be considered as good substitute ingredient ground maize in diets for broiler chickens and livestocks up to $30 \%$ of potato waste. Furthermore, Ghazalah et al. (2002) showed that yellow corn energy could be replaced by either $25 \%$ date stone or $50 \%$ potato by-product meal without harmful effect on the performance and feed utilization of Nile tilapia. The above findings confirm the present study with FJB meal for red tilapia fingerlings. No mortality was found in fish group fed all the diets during the experimental period showing no adversely effect on performance by using FJB (Table 3). When FJB replace with bran, the fish fed diet containing 25 and 50\% replacement level should less feed intake and protein intake (Table 4). However, no significant differencies $(\mathrm{P}>0.05)$ in feed and protein intakes among fish fed diets containing FJB levels were observed. Energy intake by fish fed the diets were insignificant $(\mathrm{P}>0.05)$. No significant differences $(\mathrm{P}>0.05)$ in FCR values were found among treatments contained FJB upto 50\% compared to the control group (Table 4). Meanover, the poorest values were obtained by fish given either 75 or $100 \%$ of FJB replaced wheat bran. Similar results were obtained by El-Aiatt (1999), Ghazalah et al. (2002).

Protein utilization (PER and PPV\%) decreased with increasing FJB levels (Table 4). However, $25 \%$ FJB substitution level gave similar protein efficiency ratio and productive protein value of the control group. Higher levels of FJB (75 and 100\% replacement level) gave the poorest protein utilization (Table 4). Energy utilization showed the same trend was found in PER and PPV\%. It is possible that inhibition of amino acid transport accounts for the inferior protein retention of red tilapia fed diets containing potato by-product at levels greater than 25\% replaced yellow corn (Hokazone, et al. 1979). Hasanain (1991) demonstrated that Nile catfish, Clatias lazera, was able to utilize a diet containing $66 \%$ nonconventional protein supplemented (Tomato pulp, brewers dried gain meal and bean haulms). Fish fed such diets recorded the lowest body weight gain, the lowest protein and energy intakes.

The whole body composition of the red tilapia fingerlings fed different levels of FJB is presented in table (5). The results revealed that no significant differences $(\mathrm{P}>0.05)$ in crude protein, ether extract, ash and energy contents were observed among all fish groups fed diets 
Table 2: Chemical proximate analysis of the experimental diets.

\begin{tabular}{|c|c|c|c|c|c|c|}
\hline \multirow[t]{2}{*}{ Item } & \multirow[t]{2}{*}{ FJB $^{1}$} & \multicolumn{5}{|c|}{ Diet No. } \\
\hline & & 1 & 2 & 3 & 4 & 5 \\
\hline $\begin{array}{l}\text { Dry matter\% } \\
\% \text { DM }\end{array}$ & 94.56 & 94.90 & 95.60 & 94.90 & 95.50 & 95.80 \\
\hline Crude protein & 15.06 & 37.90 & 37.75 & 38.06 & 37.91 & 37.88 \\
\hline Ether extract & 3.58 & 10.54 & 10.49 & 10.63 & 10.57 & 10.55 \\
\hline Crude fiber & 11.95 & 3.67 & 3.98 & 4.47 & 4.86 & 5.19 \\
\hline NFE & 60.69 & 36.76 & 37.03 & 35.76 & 35.38 & 35.37 \\
\hline Ash & 8.72 & 11.10 & 10.75 & 11.08 & 11.08 & 11.01 \\
\hline Calculated energy (kcal/ & diet) & & & & & \\
\hline Gross energy & 375 & 470 & 471 & 471 & 471 & 471 \\
\hline Digestible energy & 335 & 393 & 393 & 391 & 389 & 389 \\
\hline $\mathrm{P} / \mathrm{E}$ ratio $\mathrm{mg} \mathrm{CP} / \mathrm{kcal} \mathrm{DE}$ & -- & 96.69 & 96.06 & 97.34 & 7.46 & 97.55 \\
\hline
\end{tabular}

1- Fig jam by-product.

Table 3: Growth performance and survival rate of red tilapia fingerlings fed diets containing different levels of Fig. jam byproduct.

\begin{tabular}{|c|c|c|c|c|c|c|}
\hline \multirow[t]{2}{*}{ Item } & \multicolumn{5}{|c|}{ Diet No. } & \multirow[t]{2}{*}{ MSE $^{1}$} \\
\hline & 1 & 2 & 3 & 4 & 5 & \\
\hline Initial weight $\mathrm{g} / \mathrm{fish}$ & 2.13 & 2.13 & 2.13 & 2.12 & 2.13 & 0.01 \\
\hline Final weight $\mathrm{g} /$ fish & $21.30^{\mathrm{a}}$ & $18.95^{\mathrm{b}}$ & $18.20^{\mathrm{bc}}$ & $16.70^{\mathrm{c}}$ & $16.55^{\mathrm{c}}$ & 0.61 \\
\hline $\mathrm{g} /$ fish & $19.17^{\mathrm{a}}$ & $16.82^{\mathrm{ab}}$ & $16.08^{\mathrm{ab}}$ & $14.57^{\mathrm{b}}$ & $14.42^{\mathrm{b}}$ & 0.66 \\
\hline $\mathrm{SGR}^{3} \% /$ day & $4.12^{\mathrm{a}}$ & $3.90^{\mathrm{ab}}$ & $3.84^{\mathrm{ab}}$ & $3.68^{\mathrm{b}}$ & $3.66^{\mathrm{b}}$ & 0.06 \\
\hline Survival rate $\%$ & 100 & 100 & 100 & 100 & 100 & $0.00^{\mathrm{ns}}$ \\
\hline
\end{tabular}

${ }^{*}$ Values in the row having a common superscript letter are not significantly different $(\mathrm{P}>0.05)$.

1. Standard error of the means derived from the analysis of variance.

2. Gain= (final weight-initial weight).

3. Specific growth rate $=100$ (Ln final weight-Ln initial weight) day.

Table 4: Feed and nutrient efficiency utilization of red tilapia fingerlings fed diets containing different levels of Fig. jam byproduct.

\begin{tabular}{|c|c|c|c|c|c|c|}
\hline \multirow[t]{2}{*}{ Item } & \multicolumn{5}{|c|}{ Diet No. } & \multirow[t]{2}{*}{ MSE } \\
\hline & 1 & 2 & 3 & 4 & 5 & \\
\hline \multicolumn{7}{|c|}{ Feed and nutrient intake } \\
\hline Feed intake & $20.02^{\mathrm{a}}$ & $18.06^{\mathrm{b}}$ & $17.97^{\mathrm{bc}}$ & $17.86^{\mathrm{bc}}$ & $17.07^{\mathrm{bc}}$ & 0.44 \\
\hline Protein intake $\mathrm{g} / \mathrm{fish}$ & $7.22^{\mathrm{a}}$ & $6.52^{\mathrm{b}}$ & $6.49^{\mathrm{b}}$ & $6.47^{\mathrm{b}}$ & $6.20^{\mathrm{b}}$ & 0.12 \\
\hline Energy intake kcal & 89 & 81 & 80 & 79 & 76 & $0.71^{\mathrm{ns}}$ \\
\hline \multicolumn{7}{|c|}{ Feed and nutrient efficiency } \\
\hline $\mathrm{FCR}^{2}$ & $0.99^{\mathrm{b}}$ & $1.04^{\mathrm{b}}$ & $1.06^{\mathrm{a}}$ & $1.17^{\mathrm{a}}$ & $1.14^{\mathrm{a}}$ & 0.03 \\
\hline $\mathrm{PER}^{3}$ & 2.66 & 2.57 & 2.48 & 2.26 & 2.33 & 0.54 \\
\hline $\mathrm{PPV}^{4} \%$ & $41.86^{\mathrm{a}}$ & $40.01^{\mathrm{a}}$ & $33.26^{\mathrm{bc}}$ & $33.28^{\mathrm{bc}}$ & $31.47^{\mathrm{c}}$ & 1.28 \\
\hline $\mathrm{ER}^{5} \%$ & $36.53^{\mathrm{a}}$ & $34.84^{\mathrm{a}}$ & $34.33^{\mathrm{ab}}$ & $29.94^{\mathrm{b}}$ & $28.02^{\mathrm{c}}$ & 1.05 \\
\hline
\end{tabular}

${ }^{*}$ Values in the row having a common superscript letter are not significantly different $(\mathrm{P}>0.05)$.

1. Standard error of the means derived from the analysis of variance.

2. Feed conversion ratio $=D M$ intake/weight gain .

3. Protein efficiency ratio= weight gain/protein intake.

4. Productive protein value $=100$ (protein gain/protein intake $)$.

5. Energy retention $\%=100$ (gross energy gain/gross energy intake). 
Table 5: Body composition ${ }^{\text {ns }}$ of red tilapia fed different levels of Fig. jam by-product.

\begin{tabular}{lcccccccc}
\hline \multirow{2}{*}{ Diets } & Initial fish & \multicolumn{5}{c}{ Diet No } & \multicolumn{2}{c}{ SEM $^{*}$} \\
\cline { 3 - 8 } & & $\mathbf{1}$ & $\mathbf{2}$ & $\mathbf{3}$ & $\mathbf{4}$ & $\mathbf{5}$ & \\
\hline Moisture & 79.00 & 71.91 & 72.41 & 71.88 & 72.82 & 75.49 & 0.59 \\
Crude protein & 11.79 & 15.41 & 15.31 & 15.08 & 14.46 & 13.35 & 0.38 \\
Ether extract & 3.98 & 8.10 & 8.02 & 8.19 & 7.80 & 7.11 & 0.23 \\
Ash & 4.23 & 4.70 & 4.25 & 4.85 & 4.85 & 4.12 & 0.12 \\
Energy kcal/100g & 104 & 164 & 162 & 163 & 159 & 143 & 3.70 \\
\hline
\end{tabular}

ns means not significant

* Standard error of the means derived from the analysis of variance.

Table 6: Cost-benefit analysis of red tilapia fed different levels of Fig jam by-product.

\begin{tabular}{|c|c|c|c|c|c|c|}
\hline \multirow{2}{*}{ Diet } & \multicolumn{5}{|c|}{ Diet No } & \multirow{2}{*}{$\operatorname{MSE}^{1}$} \\
\hline & 1 & 2 & 3 & 4 & 5 & \\
\hline Cost per $\mathrm{kg}$ feed ${ }^{2}$ & 2.08 & 2.05 & 1.99 & 2.02 & 1.97 & - \\
\hline Incidence cost ${ }^{3}$ & $2.17^{\mathrm{a}}$ & $2.23^{\mathrm{a}}$ & $2.26^{\mathrm{ab}}$ & $2.44^{b}$ & $2.33^{\mathrm{c}}$ & 0.05 \\
\hline Profit index ${ }^{4}$ & $2.77^{\mathrm{a}}$ & $2.72^{\mathrm{a}}$ & $2.66^{\mathrm{ab}}$ & $2.46^{\mathrm{c}}$ & $2.58^{\mathrm{bc}}$ & 0.05 \\
\hline
\end{tabular}

1 - Standard error of the means derived from the analysis of variance.

2 - Kilogram cost of fishmeal, soybean meal, wheat bran, corn starch, Fig jam by-product, corn oil, vitamin premix, ascorbic acid and minerals premix were 3.8,1.5, 0.65, 1.0, 0.1, 2, 3.5, 12 and 3.5, respectively. Cost in Egyptian Pounds 1Euro equals 7.5 EGP

3 - Incidence $\operatorname{cost}=$ feed cost to produce $1 \mathrm{~kg}$ fish

4 - Profit index = value of fish $/$ cost of feed consumed, $1 \mathrm{~kg}$ fresh fish equals $6 \mathrm{LE}$.

containing FJB and the control group. Higher FJB levels resulted in a decrease in protein and ether extract contents while ash and energy contents were not affected by increasing FJB levels in diets. The cost-benefit analysis of feeding red tilapia diets containing FJB as an energy source are presented in (Table 6). It could be noticed that the price of $\mathrm{kg}$ of the diets was gradually decreased by increasing FJB level. The incidence cost for diets containing upto $50 \%$ FJB was insignificant $(\mathrm{P}>0.05)$ when compared with the control diet. Similar trend was found with the profit index. It seemed that using of FJB upto $50 \%$ in diets of red tilapia was economically efficient under the present work.

\section{Conclusion}

Fig jam by-product could be utilize by tilapia safely and efficiently as an alternative energy source upto $50 \%$ replaced wheat bran to meet a part of fish feed shortage.

\section{References}

Abdel-Hakim, N.F., Al-Azab, A.A. \& El-Kholy, K.F. 2003. Effect of feeding some full fat oil seeds on performance of tilapia hybrid (Oreochromis niloticus $x O$. aureus) reared in tanks. Egyptian Journal of Nutrition and Feeds, 6 (Special issue): $389-403$.

Abdel Munaem,A.E. 1998. Evaluation of the nutritional value of the dehydrated leaves waste of some vegetable crops in diets of Nile tilapia(Oreochromis Niloticus, trewaves) Niloticus. Ph.D., Faculty of Agriculture, Alexandria University.

AOAC 1990. Offical methods of analysis of the association of official analytical chemists. $15^{\text {th }}$ edn, Association of official analytical chemists, Virginia,USA.

AOAD 1998. Arab agricultural statistics yearbook, Arab Organization for Agricultural Development, Khartoum. 
Barreveld WH 1993. Date palm products. FAO .Agriculture Services Bulletin, Rome.

Belal, I.E.H. \& Al Jasser, M.S. 1997. Replacing dietary starch with pitted date fruit in Nile tilapia Oreochromis niloticus (L.) feed. Aquaculture Research, 28 (6): 385-389.

DUNCAN, D.B. 1955. Multiple range and multiple F tests», Biometrics, 11:1-42.

El-Aiatt, A.A. 1999. The use of non-conventional sources in diets of fish farms.M.Sc., Faculty of Environmental Agricultural Sciences, Suez Canal University.

El Baghdadi, A.H. 1995. Date stone meal as an ingredient in laying quail feed. Egyptian Poultry Sciences, 15: 153-167.

EI Dakar, A.Y. 1999. Use of dried acacia leaves in formulated diets of rabbitfish (Siganus rivulatus) fingerlings. Egyptian journal of Nutrition and feeds, 2 (Special issue): 779-792.

Garling, D.L.,Jr \& Wilson, R.P. 1976. Optimum dietary protein to energy ratio for channel catfish fingerlings, Ictalurus punctatus». Journal of Nutrition, 106 (9): 13681375 .

Ghazalah, A.A. \& Gomaa, I.A. and Hayam D. Tansy 2002, «The use of date stone meal (DSM) and potato byproduct meal (PBM) as nonconventional energy feed source in Nile tilapia, Oreochronis niloticus, diets.», Proceedings of the First Scientific Conference of Aquaculture, El-Arish.

Hasanain, G.D.I. 1991. The Utilization of some unconventional proteins by Nile catfish Clarias Lazera (C and V). Journal of the Egyptian German Society Zoology: Comparative Physiology, 6: 49-62.

Hokazone, S., Tanaka, Y., Katayama, T., Chichester, C.O. \& Simpson, K.L. 1979. Intestinal transport of L-lysine in rainbow trout, Salmo gairdneri. Bulletin of the Japanese Society of Scientific Fisheries, 45 (7): 845-848.

http://www.hort.purdue.edu/newcrop/proceedings1996/V3416.html\#Fig).
Hulan, H.W., Proudfoot, F.G. \& Zarkadas, C.G. 1982. Potato waste meal. 2. The nutritive value and quality for broiler chicken. Canadian Journal of Animal Science, 62 (4): 1171-1180.

Jackson, A.J., Capper, B.S. \& Matty, A.J. 1982. Evaluation of some plant proteins in complete diets for the Tilapia Sarotherodon mossambicus. Aquaculture (Netherlands), 27 (2): 97-109.

Labib, E.M.H. 1990, The use of Egyptian mallow in feeding of common carp (Cyprinus carpio L.).M.Sc., Faculty of Agriculture, Alexandria University.

Lim, C. 1997. Replacement of marine animal protein with peanut meal in diets for juvenile white shrimp, Penaeus vannamei. Journal of Applied Aquaculture, 7 (3): 67-78.

Masaoud, H.H.M. 1992. Effect of replacement of animal proteins by plant proteins in fish diets. M.Sc., Faculty of Agriculture, Alexandria University.

Mukhopadhyay, N. \& Ray, A.K. 1999. Improvement of quality of sesame Sesamum indicum seed meal protein with supplemental amino acids in feeds for rohu Labeo rohita (Hamilton) fingerlings. Aquaculture Research, 30 (8): 549557.

Munsiri, P. \& Lovell, R.T. 1993. Comparison of satiate and restricted feeding of channel catfish with diets of varying protein quality in production ponds. Journal of The World Aquaculture Society, 24 (4): 459-465.

National Research Council 1993. Nutrient requirements of fish, National Academy Press., Washington.

New, M.B. 1985. Feed and feeding of fish and shrimp. A manual on the preparation and presentation of compound feeds for shrimp and fish in aquaculture, United Nations development programme, Rome.

Osman, M.F., Salwa, M.H. \& El-Ashry, M.A. and Ali, T.A. 2003. Effect of feeding levels and stocking densities on the productive performance of tilapia fish Oreochromis niloticus reared under intensive culture system. Journal of Nutrition and Feeds, 6 (Special Issue): 433-443. 
Robinson, E.H., Rawles, S.D., Oldenburg, P.W. \& Stickney, R.R. 1984. Effects of feeding glandless or glanded cottonseed products and gossypol to Tilapia aurea. Aquaculture (Netherlands), 38 (2): 145-154.

Shalaby, S.M.H. 1998. Studies on fish production. 1.nutritional requirements of rabbitfish, Siganus rivulatus, fingerlings. Ph.D., Faculty of Agriculture, Alexandria University.
Snedecor, G.W. \& Cochran, W.G. 1974. Statistical methods, $6^{\text {th }}$ edn, Iawa State University Press., Iawa, U.S.A.

Zaki, M.A.A. 1990. The use of seaweed meal in feeding of common carp, Cyprinus carpio L. M.Sc., Faculty of Agriculture, Alexandria University. 